\title{
Radio Kashmir's Attempt to Dispel Negative Impact on Kashmir Society
}

\section{Rajesh Krishan Bhat, University of Jammu, India}

\begin{abstract}
This research paper throws light upon the importance and role of Radio Kashmir as one of the most strategic and vital media tools in helping security forces, people of Kashmir and the nation in combating militancy and guarding the territorial integrity of India in Jammu and Kashmir that faces an existential problem with respect to its geo-strategic position and a very hostile neighbor in the shape of Pakistan. The paper lists and highlights many instances when the institution of Radio not only rebuffed vicious Pakistani propaganda against India on Jammu and Kashmir but successfully cleared the air on many issues that created a favorable public opinion viz-a-viz India both in times of peace and war. This commentary underscores the position of Radio which continues to perform an exemplary role in this direction even in present times due to virtual non-existence of private broadcasting channels in many (still) inaccessible areas of this border State. The paper also suggests the need to strengthen media institutions like Radio Kashmir to perform as an agency that disseminates successfully India's view point, policies and programmes and its being a modern and fast developing secular democracy that is non-existent in our neighborhood.
\end{abstract}


The militancy in Jammu and Kashmir has given birth to a number of newspapers and television channels, thereby affecting the social setup and fabric by influencing people through their write-ups and highly volatile news footages. Some of the media units over the past two decades, had openly acted as spokesmen of militants or having overtly and covertly developed strong vested interests in playing into the hands of enemy agents. Means of mass communication in our present social set up too have undergone a revolution. Internet, e-mail, e-commerce and cell phones have turned the world into a global village and terrorists and political violence movements all over the world try to make repeated use of media to achieve their objective of coercing the target government and terrorising society at large

When TV shows the terrorist act, it increases the paralysing effect of violence. It helps in creating and maintaining a debilitating level of fear which is considered essential by terrorist leaders to dry up intelligence for security forces. Television often repeats its telecasts to cater to the needs of people who may have missed the first 'break-out' exposure. At the strategic level, terrorism is highly publicity-oriented and media comes out stridently making blows on the sensitivities of the audience and viewers.

Terrorist leaders know that once a violent incident is enacted, the TV commentators will bombard their viewers with the details of their organisation and leaders. The press is bound to project the perpetrators of violence as heroes in an otherwise un-heroic world. Emotional reaction to all acts of terror is generally out of all proportions.

It is the ability of the State-controlled media to control the impact of events and inform society at large about the nefarious designs of anti-social elements. Unfortunately, in the States like Punjab, Jammu and Kashmir and North East States of India, it ha been found that some private media establishments had literary added fuel to fire by glamourizing militant acts to influence society at large.

It has, however, been All India Radio and Doordarshan not only having redubbed militant claims but informing local populace about the exaggerated versions of some private TV channels and newspapers. During the Kargil conflict of 1999, Doordarshan and All India Radio worked as force-multipliers to negate Pakistani media claims and well as a section of media within the country. The media highlighted the achievements of Indian Army and Indian 
Air Force which changed the perceptions of nation's population. National spirit came to the fore as if with the help of the magic wand of media.

Terrorists want media to project the psychology of their group. Dr Surinder Singh, who has served as Inspector General of Border Security Force, Jammu Frontier, opined that "terrorist group will not stop short of its goal and in the process will not allow any peace to anybody. Terrorist outfits want media to help them at every stage. If they cannot reach the public and the leadership of the nation, their violence is totally pointless. 'Propaganda by deed' is their guiding posture. They want that their violent movement should be talked about in society through intervention of media so that the final goal of coercion of the ruling elite can be achieved. As media denotes education and enlightenment, ideological terrorism gets consistent boost and exposition all along its period of struggle against the might of the State. ,

Before the onset of militancy in 1989, Kashmir was publishing 17 dailies and 16 weeklies ${ }^{\mathrm{i}}$. The content of these dailies was normally pro-people, pro-India and were contributing in building and cementing national interests to a large extent. Side by side, the newspapers, through their write-ups were promoting communal harmony and giving adequate coverage to national and local political parties who believed in democratic principles. However, after the outbreak of militancy, there was a sudden change in the mood of newspaper publications which had a tremendous impact on Kashmir's social fabric. There was also a sudden rise in printing of newspapers from Kashmir, who mostly thrived on promoting militancy. After 1989 till 1999, the number of dailies drastically went to 45 and that of weeklies touched 50. By 2009, this figure had gone above 60 in both cases and most of the Kashmir based vernacular press had pro-militant content to keep the pot of militancy boiling.

As if it was not enough, and in the absence of a proper national media policy, certain private electronic channels surfaced on Kashmir horizon. They too promoted and glorified militant acts; a notion that violence or terrorism is sellable and newsworthy and invites high readership, without caring for ramifications. ${ }^{\text {ii }}$

In a conflict situation that gripped Kashmir, private media did not play a healthy neutral role as a result the ongoing conflict in the valley generated hostility, animosity and consequently mistrust. It also helped in prolonging the conflict that largely affected the society, forcing a 
vast chunk of people to migrate to other parts of the nation. The role of media is creating an environment in which political discourses and identities are shaped and conflicts perceived are well acknowledged. The media not merely reports but mediates between individuals, communities, groups and Nation States. However, this seemed to have been missing especially in Kashmir. Instead, media was used as a tool to manipulate public perceptions.

The anti-India propaganda by some valley based newspapers continues during the present times. This had very recently prompted Union Ministry of Home Affairs, Government of India to recommend and initiate action against five such valley based newspapers for ill-informing masses. The Union Home Ministry in September 2011 cracked the whip on three English and two Urdu newspapers and decided to starve them of official advertisements and other support. The English newspapers were Kashmir Times, Greater Kashmir and Rising Kashmir whileas two Srinagar-based Urdu dailies include Buland Kashmir and Ethlaat. "A joint secretary in the MHA has sent a circular to 30-odd Union ministries and agencies, including public sector units, asking them to snap all advertisement and financial support to the five newspapers," a senior official said. ${ }^{\text {iii }}$

These newspapers had been charged with publishing news fostering separatism and leading to disharmony in Kashmir region. Even as the Union Home Ministry decided that newspapers with anti-national agenda will not be given any government support, the damage caused by these newspapers to the strategic interests of the nation was irreparable.

Under these circumstances when anti- India propaganda continues unabated, the Government requires a media organization with a mass base to counter such propaganda. Radio Kashmir is as the only Institution on which the government machinery has been banking upon in order to inform, educate and entertain different segments of society.

At a time when there is a mushroom growth of the news channels and every channel 'creates' its own news to push up its TRP rates, a listener is virtually confused as to what had really happened at the scene of occurrence. The treatment to news is now different for different news organizations who have failed to work on the basic theory that 'facts are sacred but comments are free'. ${ }^{\text {iv }}$ There have been many instances in Kashmir and elsewhere in the country when one TV channel tried to win over other channel by 'killing' more security forces. In some cases, 
they played with the security and stability of the nation in contravention of the Cable Network Code which categorically states that news should not jeopardize the security of the nation and care should be taken that news broadcasts are in the interest of the nation. All plans for a broadcast which explores and exposes the views of people who use or advocate violence for the achievement of political ends must be considered carefully by senior editorial/ management before any arrangements for broadcasting are made.

The Self-Regulatory Code for the TV channels further emphasizes the need that broadcasters should observe general community standards of decency and civility in news content and scheduling, taking particular care to protect the interest and sensitivities of children and general family viewing. Great care and sensitivity should be exercised to avoid shocking, offending or misleading the audience. News should be reported with due accuracy and presented with due impartiality. Accuracy requires the verification (to the fullest extent possible) and presentation of all facts that are necessary to understand a particular event or issue. Balance, or impartiality, requires the presentation of all the main points of view or interpretations of an event or an issue, Accuracy and impartiality has to be ensured regardless of whether reporter, editor or the audience agrees with these views should precede the commentary and analysis.

However, such kind of a self-regularization is not normally found being adhered to by the private media, who day in and day out play with the sentiments of the people, believe in commercialising the content of news and also ignore importance of the strategic interest of the nation. On the contrary, the culture of 'breaking news', 'paid news' or sensationalism is not a part of Radio broadcasting. The news is aired only after confirming its source. The AIR news is flashed only after going through all its pros and cons. Media men should not be gullible enough to have been manipulated by discontented elements, who feed them unsuspectingly with selective statists and perceived half-truths mixed with pure speculations. The seriousness of the matter lies in the fact that this kind of reporting has the potential to demoralise the constituent manpower of the services and undermining the homogeneity of the singularly apolitical mainstay of India's security----the armed forces. ${ }^{\mathrm{v}}$

While a section of media in Kashmir have mostly glorified militancy at the cost of ignoring people's problems and their social and cultural aspirations, Radio Kashmir on the other hand 
has earned the importance of acting as a promoter of strengthening democratic institutions in the State and the country as a whole. Broadly speaking, there are six major factors which, since Independence, have made radio listening strategically important and highly popular in Jammu and Kashmir. They are categorised as ,National Interest, Religious Diversity, Cultural Factor, Geographical Factor, Disaster Management and Radio's Fast and Vast Reach.

A number of security personnel guarding the borders in far flung areas like Poonch, Rajouri, Drass, Kargil, Zanaskar, Teetwal, Karnah, Doda etc are solely dependent on radio listening as it is the major medium to provide them information and entertainment in hostile conditions, particularly during winters when most parts of the State remain cut off . Similarly, other sections of the society too hold Radio Kashmir in high esteem, as it meets their cultural and regional aspirations. In extreme emergences like that of flood or earthquake, radio has the potential to disseminate information. The government has also promoted its schemes on National Rural Health Mission (NRHM), Agriculture, Family Planning and AIDS awareness campaigns on radio to educate rural and illiterate masses.

The State of Jammu and Kashmir comprises people of different religions, faiths, beliefs and diverse ethnicities with different groups of people speaking different languages in different regions. This diversified section of Indian society has been expecting a unique mass media which would address to their issues. As different segments of mass media including private TV channels and newspapers are generally run on commercial lines and owners promoting particular ideology, the religious and ethnic minorities do not find an adequate coverage on such commercially-run mediums. It has been Radio Kashmir, since 1947, catering to the needs of all sections of the society.

Media has many a times been criticised for being communal, which can not be the case with Radio Kashmir or any government run- media institution in the nation. The communalist elements have infiltrated the media to such an extent that even non-communal managements are compelled to toe the line and exploit the popular mood. Apart from internal subversion, another compulsion is being added by the growing power of adversaries and commercial houses, which are being manned by obscurantist and reactionary forces. There is definitely a need for alternative source of information, which could not only highlight the religious 
diversity of the nation or a State but also provide secular and objective facts and enthuse the people to combat the divisive forces. ${ }^{\mathrm{vi}}$

For its legacy and having a definite broadcasting code with coverage to all religions and sects, Radio Kashmir has the potential of being further developed as an alternative source of information. As Muslims being in majority in Jammu and Kashmir, the religious broadcasts over Radio Kashmir all these years have proved to be of great relevance and significance. In some pockets of Kashmir, television is still considered to be un-Islamic and a medium of indecency and obscenity. Radio on the other hand does not feed at least vulgar diet to the people. ${ }^{\text {vii }}$

Both Radio Kashmir Srinagar and Radio Kashmir Jammu broadcast religious programmes every day and on all important festivals. Playing of devotional music catering to all faiths is a routine affair for Radio Kashmir Srinagar and Jammu on their Primary and Yuva Vani channels. The cue sheets and fixed point charts of these stations show that Hindu Artis and Bhajans, Muslim Naats, Manqabats, and Hamds and Shabads and recitations from Guru Granth Saheb are being broadcast mostly in morning transmissions. Special programmes on the occasion of Muharram, Shivrati, Eid-ul-Fitre and Eid-ul-Zuha, Janam Ashtami, Ram Navmi, Christmas and highlighting teachings of Sikh Gurus are being broadcast over Radio Kashmir with an idea to promote the secular ethos of the country. In fact, every day, the transmission begins with 'a thought for a day’ from the teachings of great religious scholars, irrespective of their religious affiliations.

During the fasting month of Ramadan, Radio Kashmir Srinagar goes on air with a special "Sehri Transmission". Further, Radio Kashmir Srinagar is the only Station in the world which continues to have the privilege of broadcasting special mourning programmes for three days during Muharram, the first month of the Islamic calendar. The programmes are broadcast on First, Seventh and Tenth Muharram, the day of the Martyrdom of Hazrat Imam Hussain.

The beauty of these religious broadcasts is that they have been most of times scripted by people of different faiths for meeting the religious aspirations of people of all walks of life. Eminent broadcaster and journalist Sham Kaul in his memoirs on importance of Radio Kashmir recalls: 
"From Hakim Mohi-ud-din to Ashraf Sahil; from Prem Nath Pardesi to Rafiq Raaz; from Gwashlal Kaul to Ashok Handoo; from Raj Begum to Shamima Dev and Kailash Mehra; from Ghulam Qadir Langoo to Rashid Hafiz; from Ghulam Mohammad Rah to Ghulam Nabi Sheikh; from Niza Saab to Machama and Moma Pipji; from Yusuf Qadri to Ajit Singh; from Jawabi Hamla to Vaadi Ki Awaz; from Nadim's Bombur Yemberzal to his Veth, from Tibet Baqal's 'Bel Tai Madal' to Aima's 'Ya Nabi Gosh Faryadan Thav'; from Dastane Himal Nagrai to Lone's version of Vaital Pachisi; from Lone's Suyya to Yeth Rooz Pakan of Akhtar, Zutshi and Lone; from N L Watal's probing political analysis to Maqbool Hussain's compact commentaries; from Sham Kaul's talks on Id-ul-Zuha and Id-ul-Fitre to Maqbool's commentaries on Shiv Ratri and Janam Ashtami; from Hamza Das to Mohammad Ismail Mujgund; from Sofi's Sheshrang to Dar's Aka Nandun; it is an unending stream of a civilisational endeavour for creativity, perfection and universal relevance in broadcasting."viii

Jammu and Kashmir has the distinction of having multifaceted, variegated and unique cultural blend, making it distinct from the rest of the country, not only from different cultural forms and heritage, but from geographical, demographically, ethical, social entities, forming a distinct spectrum of diversity and diversions into Kashmir, Jammu and Ladakh, all professing diverse religion, language and culture, but continuously intermingling, making it vibrant specimens of Indian unity amidst diversity. Its different cultural forms like art and architecture, fair and festivals, rites and rituals, seer and sagas, language and mountains, embedded in ageless period of history speak volumes of unity and diversity with unparalleled cultural cohesion and cultural service. It goes without saying that Radio Kashmir has served as a promoter and preserver of this unique cultural diversity of the State. The traditional folk music of the State is in fact only available with Radio Kashmir, as a number of rich and archival recordings are preserved and digitalized in the broadcast libraries of this media institution. In fact the Unique Selling Proportion (USP) of playing traditional Kashmiri, Dogri, Gojri, Pahari and Ladakhi music is vested only with Radio Kashmir.

Music is the soul of any broadcasting institution, more so when it is linked with the culture of the area. Jammu, the land of the Dogras, offers an entirely different fare of dances and music, 
which has been preserved by Radio Kashmir Jammu. A number of folk songs, linked with heroism and bravery, have been recorded by the Station reflecting the fact that over the centuries long spell of separation from their soldier husbands and brothers have led the hardy but graceful women of the region to evolve many diverting dances and songs to keep themselves in cheer in their free moments. The songs of separation, the ever increasing yearning for reunion with the beloved, the hard life on the mountain slopes and various other themes connected with their day-to-day life find their echo in the folk songs recorded over all these years by Radio Kashmir Jammu. The station has produced a number of renowned singers known for singing Karks, Baaks and Bheants.

Kashmir region on the other hand is known for its Sufi and Rishi cult. And Radio Kashmir Srinagar has been able to preserve this way of life which has a scope to accommodate every section of society, irrespective of their religious affiliation. Soofiana musiqui came to Kashmir from Iran in the 15th century. Over the years it has established itself as the classical music form of Kashmir and has incorporated a number of Indian Ragas in its body. Apart from preserving and promoting Soofiana Musiqui, Radio Kashmir's Srinagar wing has kept the rhythm of Chakri, --- the most popular form of Kashmiri folk music reverberating .

It is widely said had there been no institution like Radio Kashmir in Jammu and Srinagar, the folk music of the State would have vanished and artists having failed to achieve recognition. Radio Kashmir has to its credit of having enriched the diversified culture of the State. No mass media other than Radio Kashmir has given such a promotional coverage to Dogri, Kashmiri, Punjabi, Gojri and Ladakhi literature. Eminent personalities like Gyan Peeth awardee Prof Rehman Rahi and Padam Shris Pushkar Bhan, Som Nath Sadhu, Maryam Begum, Amin Kamil, Dr Jatindra Udhampuri, Prof Ram Shastri or Sahatiya Academi or Sangeet Natak Academy awardees like Mohan Singh or Krishna Kumari are the creation of Radio Kashmir. ${ }^{\text {ix }}$

Further, if Dogri was included in the $8^{\text {th }}$ Schedule of the Constitution, it was equally because of a series of literary programmes broadcast over Radio Kashmir Jammu and to mobilise the public opinion for the cause. Prof Nilamber Dev Sharma, former Secretary of Jammu and Kashmir Academy of Art, Culture and Languages in his radio talk`Role of Radio Kashmir Jammu in Preservation and Promotion of Dogri Language and Culture', admits that Dogri got boost through Radio Kashmir Jammu, as programmes broadcast over Radio Kashmir Jammu 
help people in getting linked to the roots. Sharma feels that this has been the biggest contribution of Radio Kashmir Jammu as the Station helped in giving recognition to the local language. He acknowledges the fact that this could be the major reason for people to listen to Radio Kashmir Jammu as the Station has helped in linking people of the region who have a unique culture to boast upon. ${ }^{\mathrm{x}}$

Some prominent Dogri writers who have remained associated with Radio Kashmir Jammu and contributed in the growth of Dogri prose and poetry through Radio, include Kishen Smailpuri, Thakur Poonchi, Chanchal Sharma, Ved Rahi, Jatinder Sharma, Ram Kumar Abrol, K S Madhukar, Yash Sharma, Pradhuman Singh, Krishna Kumari, Vishnu Bhardwaj, Dr Ashok Jerath, Prof Madan Mohan Sharma, Padma Sachadev and Dr Ved Kumari Ghai.

Dr Jatindra Udhampuri, a noted Dogri scholar, a Sahatiya Akademi and Padam Sri awardee, feels that over the years Dogri language has got a raw deal by media. He, however, takes pride in saying that Radio Kashmir Jammu has been the only institution in promoting this language. Dr Udhampuri, who has a distinction of having also served as Director of Radio Kashmir Jammu, opined that Dogri dramas and the local music aired from Radio Jammu have also captured the listeners even from across the border ${ }^{\mathrm{xi}}$.

Like Dogri, Radio Kashmir Jammu has equally promoted Gojri for which daily programmes are being broadcast to cater to the needs of Gojri speaking population which normally live a life of nomads in far-flung and hilly areas. Eminent Gojri scholar, Hassan Parvaz says it is mainly because of Radio Kashmi Jammu that Gojri language and Gujjar community got a boost in preserving their culture and language. ${ }^{\text {xii }}$

Syed Qaisar Qalander, former Deputy Director General of All India Radio in his last radio talk: "Radio Kashmir and Kashmiri Language" credited Radio Kashmir Srinagar for ushering in a renaissance of Kashmiri culture. This talk was broadcast on May 14, 1998, before his sudden demise on June 6, 1998. Sh Qalander acknowledges Kashmiris' strong bond with Radio Kashmir, as the institution has made it possible and comprehensible to talk about arts, literature, science and technology and historical events and personalities of the past. ${ }^{\text {xiii }}$ 
Apart for promotion of Kashmiri and Dogri languages, Radio Kashmir devotes a good chunk of time to Urdu language, which incidentally is an official language of the State during the times of Maharajas and binds the three distinct regions of the State.

As many parts of the State fall in shadow zones where TV signals either hardly reach or have a blurred reception, the mountainous terrains and other geographical obstructions on the other hand fail to stop radio waves to reach the masses. Since radio waves are not VHF, they are reflected back by the radio mirror (Ionosphere), about 60-100 kilometers away from the earth, whereas the TV signals (NHF), penetrate through the ionosphere and do not reflect back. Also, due to the disappearance of some of the layers during the day, the reception is poor, compared to the reception in the evening. This is the main reason, why foreign radio services like BBC, Voice of America etc are not clearly heard during the day and local signals of Radio Kashmir have all time high reception ${ }^{\text {xiv }}$.

Jammu and Kashmir has a high potential to be self-sufficient in generating electricity from its rivers but the same has not been fully tapped, as a result of which the State is witness to horrible power cuts every season in all regions. The most affected areas are the higher and upper reaches which during most parts of the harsh winter every year, remain cut off from the rest of world. As power lines get snapped due to heavy and continuous snowfall for days together, the hapless people have only radio as a trusted medium to bank upon and also to highlight their plight so that authorities mobilise their men and machinery.

Radio has proved that it can be best medium during extreme natural disasters like earthquakes or in an act of militancy related emergency to interact with the affected people. It has many a time proved to be extremely beneficial for thousands of such passengers who got stranded for days together on the Jammu-Srinagar national highway due to heavy snowfall landslides.

Since entire Kashmir valley falls in the most dangerous seismological Zone- $\mathrm{V}$, the role of Radio Kashmir in any such kind of emergency can not be underestimated. This was ably demonstrated by Radio Kashmir during the killer earthquake of October 13, 2005 that rattled entire Kashmir valley and PoK. 
Radio Kashmir with a vast reach went on to maintain an uninterrupted link without needing power supply which was snapped in the most affected areas like Uri, Tanghdar, Karnah and Poonch. The importance of Radio Kashmir in such situations has compelled State government to enlist it as an important member of the City Disaster Management Committee (CDMC) for Srinagar. ${ }^{\mathrm{xv}}$

In 2008 also, a series of earthquakes in the valley rattled the psyche of Kashmiris and people started to nourish different types of phobias, as rumor mongers were spreading all types of canards attached with earthquakes. It was during the months of February and March 2008 when Kashmir was rattled eight times and rumor was agog that more quakes will follow in particular areas like the one of October 2005, which was measured 7.7 on the Richter scale. In the absence of adequate knowledge about the quakes, the people had begun to cook up stories according to their own tastes and making wild guesses while depending upon rumour mongers and their 'inputs'.

It was after marathon efforts by Aamir Ali, then project coordinator, United Nations Development Programme (UNDP) Disaster Management who utilized the services Radio Kashmir to convince the people that no earthquake could be predicted and further earthquakes have been occurring in Kashmir since times immemorial. It was in 1555 and 1885, when two major earthquakes had destroyed apple rich belt of Sopore in North Kashmir. Many more such earthquakes had also been recorded in Kashmir, including that of October 2005 that had an epicentre in Muzzafarabad in Pakistan Occupied Kashmir (POK).

Apart from quakes, Jammu and Kashmir is every year hit by other types of natural calamities in the shape of snow-tsunami, avalanches, forest fires or floods and many innocent lives are lost. Radio has the potential to make people aware about taking necessary precautions, particularly at the times of tremors and the aftershocks. Earthquakes take people by surprise but media, especially radio with a fast and vast coverage, can prepare people to meet any kind of eventuality. ${ }^{\mathrm{xi}}$

Radio is the only medium which provides news before it is printed. Unlike print journalism, radio news and information on important government decisions and schemes reach the masses within no time. With a large network of radio stations and high power transmitters in the State, 
the local, national and international happenings reach the masses well in time and more so in their own language and dialect. A listener does not necessarily need to be a literate. He can have access to the happenings taking place around him in no time. Further, broadcaster does not need to wait for a camera, visuals or a make-up to build an emotional chord with the listeners. Further, as per 2011 census, the average literacy rate of Jammu and Kashmir was 68.74 percent, $(78.26 \%$ male and $66 \%$ female). Therefore, radio is the best medium to reach rest of the population of the State who can not read newspapers or magazines for news and information. To add to it, 70 percent population of the State including Gujjars, Bakerwals and Paharis live in hilly and remote areas and have no medium other than radio to bank upon. As such, no medium can compete with radio for its fast and vast reach.

\footnotetext{
${ }^{\mathrm{i}}$ Major General Arjun Ray ( 1997), Kashmir Diary Psychology of Militancy, New Delhi: Manas Publications ii Ibid

iii Daily Excelsior, Jammu, dated 27 November 2011; pp: 5

iv The theory has been propounded by noted British Journalist C P Scot.( 1846 to 1932). Scot was the editor of the Manchester Guardian from 1872 until 1929

${ }^{v}$ Saxena, Sangeeta( 1997),Defence Journalism in India, New Delhi: Manas Publications ,Pp:13

${ }^{\text {vi }}$ ST Correspondent ( 1989), “'Media criticised for being communal”, The Statesman, New Delhi, 16 October 1989.

vii Hyderi, Zafar (2001), Radio in Kashmir, Lucknow: Hyderi Publications

viii Golden Jubilee Celebrations Souvenir of Radio Kashmir Srinagar ( 1948-1998) Radio Kashmir: Five decades of excellence,', Pages: 28-30.

${ }^{\text {ix }}$ Srijan (Hindi), A Radio Kashmir Srinagar Publication ( 2006)

${ }^{\mathrm{x}}$ The talk of archival value was broadcast over primary channel of Radio Kashmir Jammu on December 13, 1997

${ }^{x i}$ Bhat, Rajesh ( 2009), “'Udhampuri adds new chapter to Dogri literature', The Tribune J\&K Plus, Chandigarh,29 April, 2009

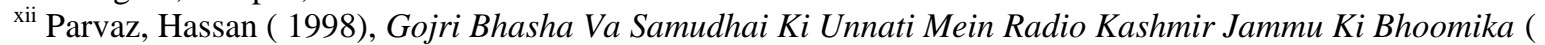
Hindi), Akashwani Club, Radio Kashmir Jammu Publication.

xiii The transcribed version of the talk finds a mention in Golden Jubilee Souvenir of Radio Kashmir Srinagar ( 1948-98)

${ }^{\text {xiv }}$ Hyderi, Zafar (2001), Radio in Kashmir, Lucknow: Hyderi Publications.

${ }^{\mathrm{xv}}$ Kashmir Divisional Commissioner order number Div Com-K/806/2006, Dated: 16. 12. 2006

${ }^{\text {xvi }}$ Major General Arjun Ray ( 1997), Kashmir Diary Psychology of Militancy, New Delhi: Manas Publications
} 